\title{
The Effect of Positive Pressure Ventilation on Aldosterone Level in Critically Ill Patients; Correlation with Renal Function and the Length of Stay in ICU
}

HEBA YEHIA, M.Sc.; HOSSAM MOWAFY, M.D.; HAZEM EL AKABAWY, M.D.; AHMED SAMIR, M.D. and ADEL ELSISI, M.D.

The Department of Critical Care, Faculty of Medicine, Cairo University

\begin{abstract}
Background: Positive pressure ventilation has been shown to alter a variety of neurohormonal systems including sympathetic outflow, the renin-angiotensin axis, nonosmotic vasopressin $(\mathrm{ADH})$ release and atrial natriuretic peptide (ANP) production. The end result of all of these neurohormonal pathways is diminished renal blood flow, decreased GFR, and fluid retention (salt and water) with oliguria.
\end{abstract}

Aim of Study: To investigate the effect of positive pressure mechanical ventilator on aldosterone and to study its prognostic value.

Patients and Methods: This study was conducted on 50 patients admitted to the intensive care unit (ICU) and needed mechanical ventilation and did not meet any of exclusion criteria and 25 control (critically ill patients who did not need mechanical ventilator). The patients were divided into 2 equal groups; group I with high PEEP (10-15) and group II with physiological PEEP (3-5).Aldosterone level was measured for these patients on first day of using PPV (aldosterone 1) then after $72 \mathrm{~h}$ (aldosterone 2).

Results: Aldosterone levels were increased with use mechanical ventilation and were significantly higher with higher level of PEEP. There were correlations between aldosterone 2 with urea and Creatinine levels and with length of ICU stay only in patient group $(p<0.001)$.

Conclusion: Mechanical ventilation caused elevation of aldosterone levels. Aldosterone levels in mechanically ventilated patients correlated with kidney function test (urea and Creatinine) and with length of ICU stay.

Key Words: PPV-Aldosterone-Mechanical ventilation.

\section{Introduction}

MECHANICAL ventilation can be lifesaving but it is also associated with numerous complications. The incidence of some complications increases with duration of mechanical ventilation [1]. There are numerous mechanisms underlying the develop-

Correspondence to: Dr. Heba Yehia, The Department of Critical Care, Faculty of Medicine, Cairo University ment of complications in the ventilated patient. Complications may result from the endotracheal tube or tracheotomy tube (or with noninvasive ventilation, the mask), or from the effects of positive-pressure ventilation. Some complications (barotrauma and volutrauma) can result from either the underlying lung disease or the effects of lung overdistension produced by positive-pressure ventilation [2]. Complications may result from therapies or the process of care required by most invasively ventilated patients (e.g., immobility and risk of thromboembolism). Other complications may occur as a manifestation of critical illness or underlying comorbid conditions [3,4].

Physiological consequences of mechanical ventilation on pulmonary and cardiovascular function have been studied extensively, [5] and many investigators have shown that positive-pressure ventilation affects venous return, cardiac pre-load, pulmonary vascular resistance, and cardiac afterload $[6,7]$. In addition to these direct physiological effects, mechanical ventilation may exacerbate lung injury and cause ventilator-induced lung injury (VILI), resulting in the local and systemic release of inflammatory mediators, organ dysfunction, and increased morbidity and mortality [8].

Although the physiological consequences of mechanical ventilation on pulmonary and cardiovascular function have been extensively studied, its effects on renal function are not as well defined. [9].

\section{The aim of study:}

To investigate the effect of positive pressure mechanical ventilator on aldosterone and to study its prognostic value. 


\section{Patients and Methods}

This study was conducted on 50 patients admitted to the intensive care unit (ICU of Misr University for Science and Technology Teaching Hospital) and need mechanical ventilation and 25 control (critically ill patients did not need mechanical ventilation) in the period from 2012 to 2015 .

\section{Patient selection:}

Patients who need mechanical ventilation on ICU admission and did not meat any of the exclusion criteria were selected into the study and they had been followed-up till the day of discharge or demise. Most of patients in this study were traumatic brain injury to fulfil the exclusion criteria.

\section{Exclusion criteria:}

- Patients with chronic renal impairment.

- Patients with chronic lung disease (e.g. COPD, bronchial asthma, interstitial pulmonary fibrosis).

- Primary pulmonary hypertension

- Patients with advanced heart failure, acute myocardial infarction and hemodynamically unstable patients.

- Post-arrest patient.

- Patients with severe sepsis or septic shock.

- Patients with liver cirrhosis.

- Patients with terminal malignancy.

- Patient age <18 years old.

- Pregnant female patients.

- Patients with autoimmune disease.

Patients subdivided into two groups:

Group I: Patients on mechanical ventilation and need high level of PEEP $(10-15 \mathrm{cmH} 2 \mathrm{O})$, they include 25 patients.

Group II: Patients on mechanical ventilation with lower level of PEEP ( 5 or less) (i.e. physiological PEEP), they include 25 patients.

Control group include 25 critically ill patients admitted to ICU and did not need mechanical ventilation.

The care of patients was directed according to guidelines and was not modified by the study. Generally, the first priority was to stabilize the general condition of the patient and support them with mechanical ventilation according to their requirements.

Routine laboratory investigations were done on study day 1 and subsequently after 3 days to fulfill criteria of APACHE IV.
Labs specific for this study:

Plasma aldosterone level were measured immediately after using mechanical ventilator (aldosterone 1) and 3 days later (aldosterone 2). Blood samples were allowed to clot and then centrifuged to separate the serum according to common procedures and were measured using ELIZA technique.

\section{Principles of the test:}

The principle of the following enzyme immunoassay test followed the typical competitive binding scenario. Competition occurs between an unlabeled antigen (present in standards, controls and samples) and an enzyme-labelled antigen (conjugate) for a limited number of antibody binding sites on the microwell plate. The washing and decanting procedures removed unbound materials. After the washing step, the enzyme substrate was added. The enzymatic reaction was terminated by addition of stopping solution. The absorbance was measured on a microtiter plate reader. The intensity of the colour formed is inversely proportional to the concentration of aldosterone in the sample. A set of standards was used to plot a standard curve from which the amount of aldosterone in samples and controls could be directly read.

\section{Results}

This study included patients with age ranged from $18-80$ years with mean age $(47.36 \pm 16.15)$. Control group with age ranged from 18-74 with a mean (46.08 \pm 15.20$)$. There were 31 males (16 in group I and 15 in group II) and 19 females (9 in group I and 10 in group II) and in control group there were 15 males and 10 females.

\section{Clinical characteristics of enrolled patients:}

Clinical characteristic of control versus group I and group II:

In this study, group I had 6 hypertensive patients, 2 diabetic patients and 1 patient with ischemic heart disease. In group II there were 10 hypertensive patients, 3 diabetic patients and 1 patient with ischemic heart disease. In Control group 10 patients were hypertensive, 3 patients were diabetic, and 1 patient had ischemic heart disease. There was no statistically significant difference between group I and group II versus control as regard clinical characteristic (Table 1, Fig. 1).

\section{I- Aldosterone level in patient versus control:}

The mean aldosterone level for all patients was statistically significantly higher than that in control group. Moreover, serum aldosterone 2 level was 
significantly higher than aldosterone 1 in patients. Group I exhibited significant higher levels of aldosterone (Table 2, Figs. 2,3).

Table (1): Clinical characteristic of control versus group I and group II.

\begin{tabular}{|c|c|c|c|c|}
\hline & $\begin{array}{l}\text { Control } \\
(\mathrm{N}=25)\end{array}$ & $\begin{array}{l}\text { Group I } \\
(\mathrm{N}=25)\end{array}$ & $\begin{array}{l}\text { Group II } \\
(\mathrm{N}=25)\end{array}$ & $\begin{array}{c}p \text { - } \\
\text { value }\end{array}$ \\
\hline HTN (Y/N) & $10 / 15$ & $6 / 19$ & $10 / 15$ & 0.389 \\
\hline $\mathrm{DM}(\mathrm{Y} / \mathrm{N})$ & $3 / 22$ & $2 / 23$ & $3 / 22$ & 0.869 \\
\hline IHD (Y/N) & $1 / 24$ & $1 / 24$ & $2 / 23$ & 0.767 \\
\hline $\begin{array}{l}\text { HTN: Hyper } \\
\text { DM : Diabet } \\
\text { IHD: Ischem }\end{array}$ & Ilitus. & \multicolumn{2}{|c|}{$\begin{array}{l}\text { N: Number. } \\
\text { Y: Yes. } \\
\text { N: No. }\end{array}$} & \\
\hline
\end{tabular}

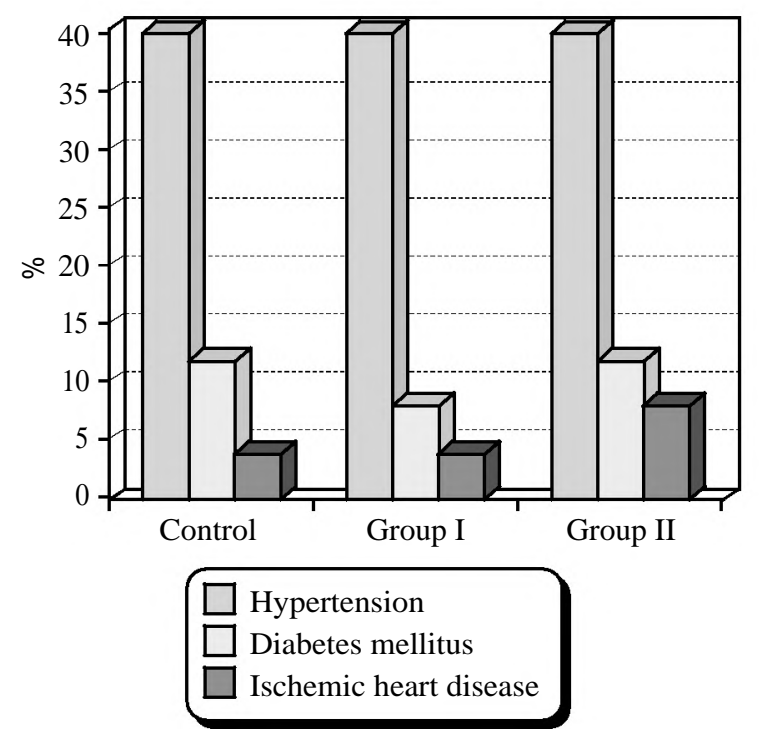

Fig. (1): Clinical characteristic of control versus group I and group II.

Table (2): Aldosterone level in patient versus control.

\begin{tabular}{llll}
\hline & $\begin{array}{c}\text { Aldosterone 1 } \\
(\mathrm{ng} / \mathrm{dl}) \\
(\mathrm{Mean} \pm \mathrm{SD})\end{array}$ & $\begin{array}{c}\text { Aldosterone } 2 \\
(\mathrm{ng} / \mathrm{dl}) \\
(\text { Mean } \pm \mathrm{SD})\end{array}$ & $\begin{array}{c}p \text { - } \\
\text { value }\end{array}$ \\
\hline Patients N=50) & $\begin{array}{l}196.64 \pm 188.74 \\
(50-750)\end{array}$ & $\begin{array}{l}287.46 \pm 216.10 \\
(60-900)\end{array}$ & 0.027 \\
Controls (N=25) & $\begin{array}{l}118.32 \pm 62.49 \\
(60-300)\end{array}$ & $\begin{array}{l}124.76 \pm 56.58 \\
(50-240)\end{array}$ & 0.737 \\
& 0.047 & 0.0005 & 0.002 \\
-value & $\begin{array}{l}176.17 \pm 167.88 \\
\text { Group I (N=25) }\end{array}$ & $\begin{array}{l}350.40 \pm 227.25 \\
(80-900)\end{array}$ & \\
Group II (N=25) & $\begin{array}{l}225.40 \pm 199.93 \\
(70-673)\end{array}$ & $\begin{array}{l}224.52 \pm 188.28 \\
(60-700)\end{array}$ & 0.987 \\
$p$-value & 0.063 & 0.000 & \\
\hline
\end{tabular}

N: Number. $\quad$ SD: Standard deviation.

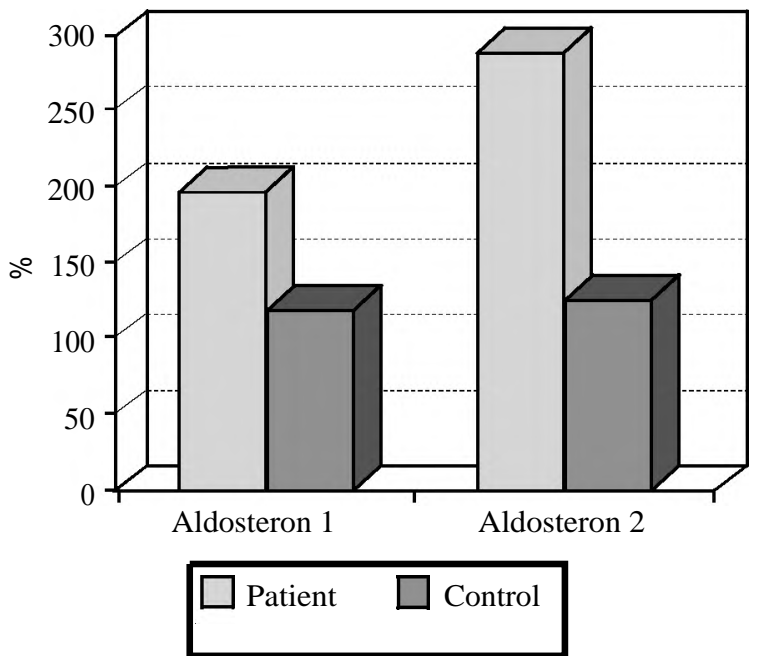

Fig. (2): Aldosteron level in patient versus control.

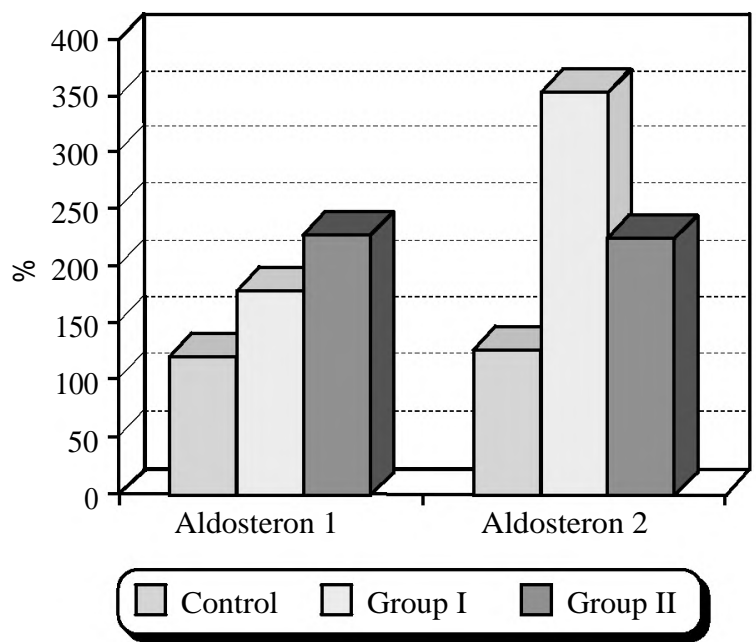

Fig. (3): Aldosterone level in controls versus group 1 and group II.

\section{II- Aldosterone levels in relation to kidney function test (KFT) (creatinine and urea):}

There was significant positive correlation between aldosterone 2 and Creatinine 2 and urea 2 in patients (Table 3 ).

Table (3): Aldosterone level versus creatinine and urea in patient.

\begin{tabular}{lllllll}
\hline & Mean \pm SD & Min Max Median & $r$ & $\begin{array}{c}p- \\
\text { value }\end{array}$ \\
\hline Aldosterone 1 & $196.64 \pm 188.74$ & 50 & 750 & 120 & -0.227 & 0.113 \\
Creatinine 1 & $0.822 \pm 0.34$ & 0.2 & 1.5 & 0.8 & & \\
Aldosterone 2 & $287.46 \pm 216.10$ & 60 & 900 & 159 & 0.356 & 0.011 \\
Creatinine 2 & $0.91 \pm 0.59$ & 0.1 & 2.7 & 0.7 & & \\
Aldosterone 1 & $196.64 \pm 188.74$ & 50 & 750 & 120 & 0.014 & 0.921 \\
Urea 1 & $36.92 \pm 30.38$ & 5 & 138 & 32 & & \\
Aldosterone 2 & $287.46 \pm 216.10$ & 60 & 900 & 159 & 0.496 & $<0.001$ \\
Urea 2 & $35.88 \pm 29.04$ & 6 & 145 & 26 & & \\
\hline
\end{tabular}

Min.: Minimum. Max.: Maximum. SD: Standard deviation.

1: Value at first day of mechanical ventilation.

2: Value in third day of mechanical ventilation. 
III- Aldosterone levels in relation to severity of illness during ICU stay:

a-Correlation between aldosterone levels with length of mechanical ventilation:

There was no significant correlation between aldosterone level with length of mechanical ventilation (Table 4).

b-Correlation between aldosterone levels with need for hemodynamic support:

There was no significant correlation in aldosterone level between patients needed hemodynamic support and those did not need hemodynamic support (Table 5).

c-Correlation between aldosterone level with length of ICU stay:

There was significant correlation between length of ICU stay and aldosterone only in patients (Table 6).

\section{IV- Correlation between aldosterone levels with mortality:}

There was no significant difference between aldosterone with mortality either in patients or control (Table 7).
Table (4): Aldosterone versus length of mechanical ventilation (LOMV)

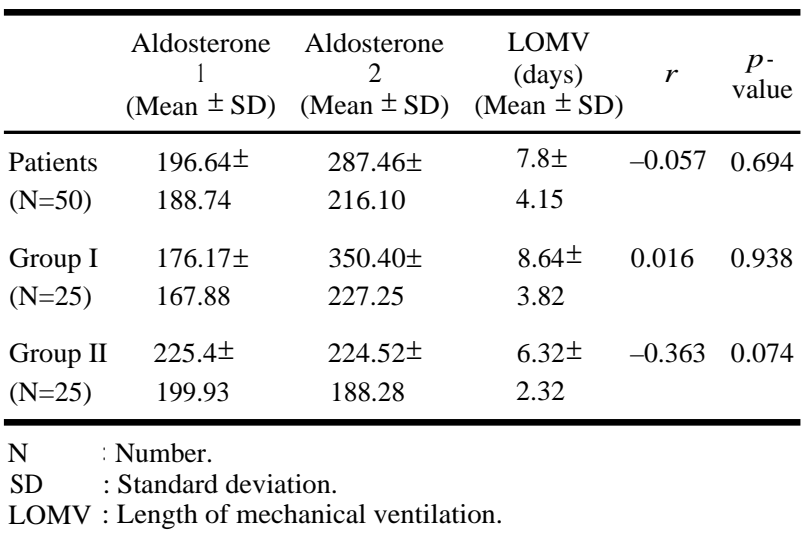

Table (5): Correlation between aldosterone with need for hemodynamic support.

\begin{tabular}{lccc}
\hline & $\begin{array}{c}\text { Patients } \\
\text { need HDS } \\
(\mathrm{N}=7) \\
(\text { Mean } \pm \text { SD) }\end{array}$ & $\begin{array}{c}\text { Patients not } \\
\text { need HDS } \\
(\mathrm{N}=43) \\
(\text { Mean } \pm \text { SD })\end{array}$ & $\begin{array}{c}p \text { - } \\
\text { value }\end{array}$ \\
\hline Aldosterone 1 & $274.28 \pm 194.75$ & $187.06 \pm 183.54$ & 0.286 \\
Aldosterone 2 & $370.0 \pm 235.16$ & $273.79 \pm 212.32$ & 0.340 \\
\hline $\mathrm{N} \quad$ : Number. & & & \\
$\mathrm{SD} \quad$ : Standard deviation. & & \\
$\mathrm{HDS}:$ Hemodynamic support & &
\end{tabular}

Table (6): Length of ICU stay (LOS) versus aldosterone in patients and control.

\begin{tabular}{llllllll}
\hline & $\begin{array}{c}\text { LOS (days) } \\
\text { (Mean } \pm \text { SD) }\end{array}$ & Aldosterone 1 & $r$ & $p$-value & Aldosterone 2 & $r$ & $p$-value \\
\hline Patients (N=50) & $9.3 \pm 6.2$ & $169.64 \pm 188.74$ & 0.051 & 0.725 & $287.46 \pm 216.10$ & 0.070 & 0.630 \\
Control (N=25) & $9.7 \pm 5.9$ & $118.32 \pm 62.49$ & 0.129 & 0.538 & $124.76 \pm 56.58$ & -0.036 & 0.864 \\
Group I (N=25) & $10.8 \pm 8.2$ & $176.17 \pm 167.88$ & 0.447 & 0.025 & $350.40 \pm 227.25$ & 0.284 & 0.168 \\
Group II (N=25) & $8.7 \pm 3.9$ & $225.40 \pm 199.93$ & -0.530 & 0.006 & $224.52 \pm 188.28$ & -0.548 & 0.005 \\
\hline
\end{tabular}

N: Number. SD: Standard deviation. LOS: Length of ICU stay.

Table (7): Correlation between aldosterone with mortality.

\begin{tabular}{llll}
\hline & $\begin{array}{c}\text { Survivors } \\
(\mathrm{N}=33)(66 \%) \\
(\mathrm{Mean} \pm \mathrm{SD})\end{array}$ & $\begin{array}{c}\text { Non-survivors } \\
(\mathrm{N}=17)(34 \%) \\
(\text { Mean } \pm \mathrm{SD})\end{array}$ & $\begin{array}{c}p \text { - } \\
\text { value }\end{array}$ \\
\hline Aldosterone 1 (pts.) & $195.67 \pm 191.21$ & $212.07 \pm 164.57$ & 0.713 \\
Aldosterone 2 (pts.) & $294.83 \pm 219.30$ & $266.46 \pm 204.33$ & 0.677 \\
Aldosterone 1 (control) & $99.22 \pm 34.98$ & $141.77 \pm 95.03$ & 0.288 \\
Aldosterone 2 (control) & $116.66 \pm 61.64$ & $143.22 \pm 49.12$ & 0.343 \\
\hline
\end{tabular}

N: Number. SD: Standard deviation. Pts.:Patients.

\section{Discussion}

Aldosterone levels increased with the use of mechanical ventilation and were significantly higher with higher level of PEEP. Aldosterone levels were significantly higher in patients than that in control group. Moreover, serum aldosterone 2 level was significantly higher than aldosterone 1 . Also aldosterone was significant higher in group I than in group II or control.

Annat G., et al. [11] measured hormonal parameters in seven intensive care patients during three consecutive 60-min periods; one of intermittent positive pressure ventilation (IPPV), one of CPPV (PEEP 10cm $2 \mathrm{O}$ ), and finally one of IPPV and found that Institution of PEEP led to a significant increase in plasma aldosterone level.

Marius G., et al. [12] who made a study on ten male patients treated postoperatively for $60 \mathrm{~min}$ using five different ventilation modes, at the end of these periods, hemodynamics, urine production, fractional excretion of sodium (FESo), as well as the hormones [atrial natriuretic peptide (ANP), renin, angiotensin II, aldosterone, and antidiuretic hormone $(\mathrm{ADH})]$ were measured. They found that renin with a positive end-expiratory pressure 
(PEEP) of $15 \mathrm{~cm} \mathrm{H} 2 \mathrm{O}$ and an inspiration/expiration ratio (I:E) of 1:2 revealed significant increases from baseline, However aldosterone, angiotensin II, and antidiuretic hormone (ADH) levels remained within the normal range.

In addition to $\mathrm{P}$ Andrivet, et al. [13] who examined the renal and hormonal responses to synthetic human ANF infusion in eight patients during mechanical ventilation with zero PEEP (ZEEP) or 10 $\mathrm{cmH} 2 \mathrm{O}$ positive end-expiratory pressure (PEEP). They determined that, compared with ZEEP, MV with PEEP was associated with increase in plasma renin activity (PRA) from 4.831 .53 to 7.853 .02 ng.ml-1.h-1 ( $p$ less than 0.05). Infusion of ANF (5 ng.kg-1.min-1) during PEEP markedly decreased plasma renin activity from 7.853 .02 to 4.401 .5 ng.ml-1.min-1 ( $p$ less than 0.05). In response to a 10ng.kg-1.min-1 ANF infusion.

On the other hand, JB Thorens, et al. [14] made a study to investigate the haemodynamic and endocrinological effects of noninvasive positive pressure ventilation. Measurements were performed on the fourth day, for 4 hours without noninvasive positive pressure ventilation and 4 hours with noninvasive positive pressure ventilation. They found that plasma renin activity, aldosterone and vasopressin were normal.

Also S. Tanaka, et al. [15] measured responses during Continuous positive pressure ventilation $(\mathrm{PEEP}=12 \mathrm{mmHg})$ in 10 male subjects $(22.0 \pm 0.6$ years, $66.8 \pm 1.5 \mathrm{~kg}$ body weight). The experiments consisted of a 1-hour control, $1 \mathrm{~h}$ with Continuous positive pressure ventilation, and a $1-\mathrm{h}$ recovery period. Two blood samples were taken during each period for measurements of arginine vasopressin (AVP), plasma aldosterone, plasma renin activity, norepinephrine, and atrial natriuretic peptide. They found that neither plasma renin nor aldosterone levels were changed.

In the current study, aldosterone levels were studied in relation to kidney function test and we demonstrated that there was a significant positive correlation between aldosterone 2 with Creatinine and urea levels only in patients.

We studied aldosterone in relation to severity of illness as; length of mechanical ventilation, length of ICU stay and mortality. This point of our study may not be found in any other equivalent research.

There was no significant correlation between aldosterone with length of mechanical ventilation and mortality.
However, there was a significant negative correlation between length of ICU stay and aldosterone 2 .

\section{Conclusion:}

Mechanical ventilation caused elevation of aldosterone levels especially with higher levels of PEEP.

We estimated a positive correlation of aldosterone levels in mechanically ventilated patients with kidney function test (urea and Creatinine).

Determination of serum levels of aldosterone may add to the clinical assessment of severity of critical illness in mechanically ventilated patients. Aldosterone 2 levels were correlated with length of ICU stay.

\section{References}

1- BENJAMIN D. SINGER and THOMAS C. CORBRIDGE: Basic invasive mechanical ventilation. South Med. J., 102 (12): 1238-1245, 2009.

2- O'CONNOR H.H.: "Prolonged mechanical ventilation: Are you a lumper or a splitter?". Respir. Care, 56 (11): 1859-60, 2011.

3- Mechanical ventilation using non-injurious ventilation settings causes lung injury in the absence of pre-existing lung injury in healthy mice. Wolthuis Esther K., Vlaar Alexander P.J., Goda Choi, Joris Jth Roelofs, Juffermans, Nicole P., et al.: Critical Care [NLM - MEDLINE] 13.1, 2009.

4- ARCHAMBAULT P.M. and ST-ONGE M.: Invasive and noninvasive ventilation in the emergency department. Emerg. Med. Clin. North Am. May, 30 (2): 421-49, ix, 2012.

5- BOUFERRACHE K. and VIEILLARD-BARON A.: Acute respiratory distress syndrome, mechanical ventilation, and right ventricular function. Curr. Opin. Crit. Care, 17: 30-35, 2011.

6- NAMENDYS-SILVA SA, et al.: Pulmonary hypertension due to acute respiratory distress syndrome. Braz J. Med. Biol. Res., 47: 904-910, 2014.

7- REPESSE X., et al.: Acute cor pulmonale in ARDS Rationale for protecting the right ventricle. Chest, 147: 259-265, 2015.

8- CHIA-TER CHAO, VIN-CENT WU and TZE-WAH KAO: Acute Kidney Injury, a Second Hit for the Prolonged Ventilated Population. International Journal of Healthcare, Insurance and Equity, Vol. 1, No 1, 2013.

9- JAY L. KOYNER and PATRICK T. MURRAY: Mechanical Ventilation and the Kidney Blood Purif, 29: 52-68, 2010.

10- LI P.K.T., BURDMANN E.A. and MEHTA R.L.: World Kidney Day 2013: Acute Kidney Injury-Global Health Alert. American journal of kidney diseases: The official journal of the National Kidney Foundation, 61 (3): 35963, 2013. 
11- ANNAT G., VIALE J.P., BUI XUAN B., HADJ AISSA O., BENZONI D., VINCENT M., GHARIB C. and MOTIN J.: Effect of PEEP ventilation on renal function, plasma renin, aldosterone, neurophysins and urinary $\mathrm{ADH}$, and prostaglandins. Critical Care Medicine, March 37.3: 1046-1053, 2009.

12- MARIUS G. DEHNE1, MARKUS MEISTER2, RAINER RÖHRIG2, CHRISTIAN KATZER2 and VALESKO MANN2: Effects of inverse ratio ventilation with PEEP on kidney function. Renal Failure, 32: 411-416, 2010.

13- ANDRIVET P., ADNOT S., SANKER S., CHABRIER P.E., MACQUIN-MAVIER I., BRAQUET P. and BRUNBUISSON C.: Hormonal interactions and renal function during mechanical ventilation and ANF infusion in humans. Biochemical and Biophysical Research Communications, 371.1 (Jun 20): 50-53, 2008.

14- THORENS J.B., RITZ M., REYNARD C., RIGHETTI A., VALLOTTON M., FAVRE H., KYLE U., JOLLIET P. and CHEVROLET J.C.: Haemodynamic and endocrinological effects of noninvasive mechanical ventilation in respiratory failure. Anesthesiology, 108 (1): 46-54, 2010.

15- TANAKA S., SAGAWA S., MIKI K., CLAYBAUGH J.R. and SHIRAKI K.: Changes in muscle sympathetic nerve activity and renal function during positive-pressure breathing in humans. Critical Care Nephrology, 10551065,2013

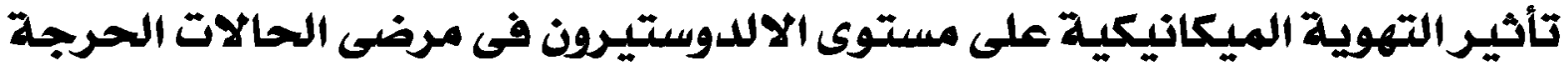

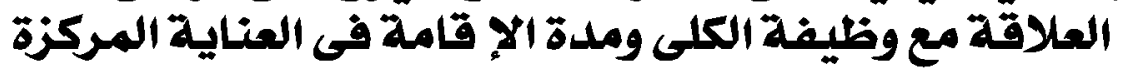

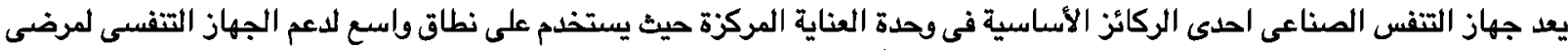

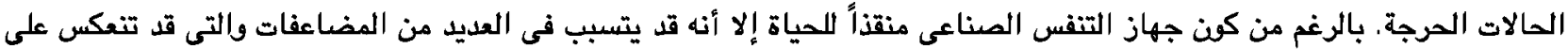

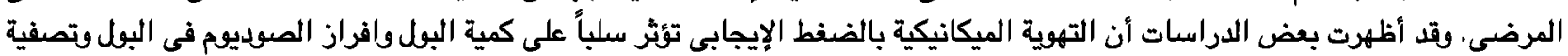
الكرياتينين.

وقد تؤثر التهوية الميكانيكية على الكلى من خلال ثلاث آليات: (1) تفيرات فى الدورة الدموية وإنخفاض النتاج القلبى وإعادة توزيع تدفق

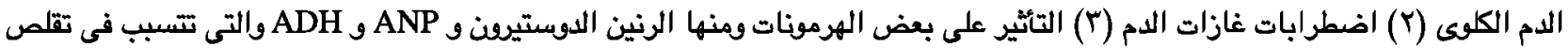

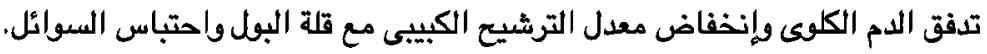

كان الهدف من هذا البحث: دراسة تأثير التهوية بالضغط الإيجابى على اللوستيرون فى المرض ذوى الحالات الحرجة الذين يحتاجون لجهاز التفس الصناعى.

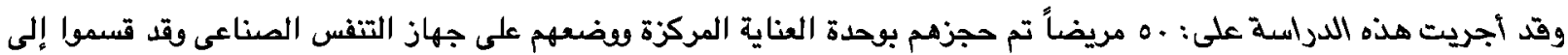

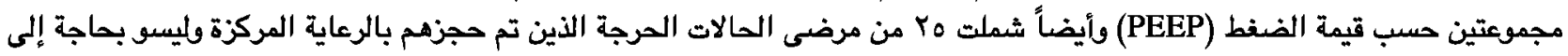
جهازالتفس الصناعى.

تم سحب عينات الدم الوريدى من هؤلاء المرضى عند وضعهم على جهاز التنفس الصناعى وبعد VY ساعة من إستخدام جهاز التفس الصناعى. وقد تم قياس تركيز الالدوستيرون بإستخدام تقنيات المقايسة المناعية الشعاعية. أنبّتَت النتائج: ارتفاع نسبة الالدوستيرئ مع استخدام جهاز التفس الصناعى وخاصة مع مستوى عال من الضغط الايجابى. وهناك صلة ذات دلالة إحصائية بين قيمة الالدوستيرون مع وظائف الكلى (اليوريا والكرياتينين) فى المرضى الذين استخدما جهاز التنفس 